\title{
Conservation of regulatory and structural genes for a multi-component phenol hydroxylase within phenol-catabolizing bacteria that utilize a meta-cleavage pathway
}

\author{
INGrid Nordlund, ${ }^{1}$ Justin Powlowski, ${ }^{2}$ ÅKe HaGström ${ }^{3}$ and Victoria Shingler ${ }^{1 *}$ \\ 'Department of Cell and Molecular Biology, Umeå University, S-901 87 Umeå, Sweden \\ ${ }^{2}$ Department of Chemistry and Biochemistry, Concordia University, Montreal, Quebec H3G IM8, Canada \\ ${ }^{3}$ Umeå Marine Research Centre, Norrbyn, S-903 04, Umeå, Sweden
}

(Received 29 April 1993; revised 1 July 1993; accepted 15 July 1993)

\begin{abstract}
Pseudomonas sp. strain CF600 can degrade phenol and some of its methylated derivatives via a plasmid (pVI150)-encoded pathway. The metabolic route involves hydroxylation by a multi-component phenol hydroxylase and a subsequent meta-cleavage pathway. All 15 structural genes involved are clustered in an operon that is regulated by a divergently transcribed transcriptional activator. The multi-component nature of the phenol hydroxylase is unusual since reactions of this type are usually accomplished by single component flavoproteins. We have isolated and analysed a number of marine bacterial isolates capable of degrading phenol and a range of other aromatic compounds as sole carbon and energy sources. Southern hybridization and enzyme assays were used to compare the catabolic pathways of these strains and of the archetypal phenol-degrader Pseudomonas $\mathrm{U}$, with respect to known catabolic genes encoded by Pseudomonas CF600. All the strains tested that degraded phenol via a meta-cleavage pathway were found to have DNA highly homologous to each of the components of the multicomponent phenol hydroxylase. Moreover, DNA of the same strains also strongly hybridized to probes specific for pVI150-encoded meta-pathway genes and the specific regulator of its catabolic operon. These results demonstrate conservation of structural and regulatory genes involved in aromatic catabolism within strains isolated from diverse geographical locations (UK, Norway and USA) and a range of habitats that include activated sludge, sea water and fresh-water mud.
\end{abstract}

\section{Introduction}

Soil and water micro-organisms, notably of the genus Pseudomonas, are capable of degrading a wide variety of naturally occurring and synthetic aromatic compounds. During aerobic metabolism of these compounds the bacteria express a battery of distinct enzyme systems to convert the substrate to di-hydroxylated destabilized ring structures, such as catechols. Catechol is an intermediate in the degradation of compounds such as benzoate, naphthalene, salicylate and phenol. Substituted catechols are intermediates in the catabolism of methylated and chlorinated derivatives of these compounds (Dagley, 1986; Reineke \& Knackmuss, 1988).

\footnotetext{
*Author for correspondence. Tel. +4690 102534; fax +4690 111420.
}

Abbreviations: C12O, catechol 1,2-dioxygenase; C23O, catechol 2,3dioxygenase.
These catechol intermediates serve as the substrates for ring fission dioxygenases and are further metabolized to Krebs cycle intermediates by one of two metabolic alternatives: those of the ortho- and meta-cleavage pathways (Dagley, 1986).

Amongst the earliest studies of phenol and cresol catabolism were those involving Pseudomonas U (Dagley \& Gibson, 1965), whose enzymes have served in many of the classical biochemical studies of the meta-cleavage pathway enzymes. We have recently reported the isolation and characterization of Pseudomonas sp. strain CF600 from activated sludge. Pseudomonas CF600 can grow efficiently with phenol, cresols or 3,4-dimethylphenol as the sole carbon and energy source (Shingler $e t$ al., 1989). The catabolic pathway for these substrates is encoded on an Inc P2 megaplasmid designated pVI150 and involves hydroxylation followed by a meta-cleavage pathway. The fifteen genes for the enzymes of this pathway are clustered in a single operon (Bartilson et al., 1990; Nordlund et al., 1990; Nordlund \& Shingler, 1990; 


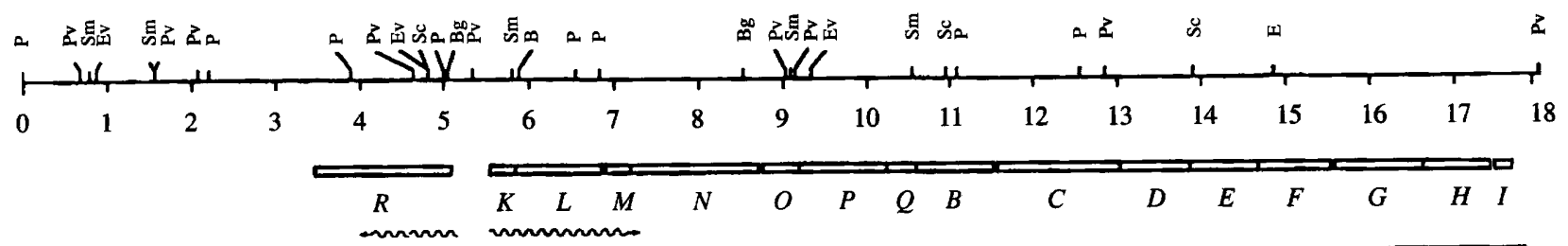

Phenol hydroxylase

meta-Cleavage pathway enzymes

Fig. 1. Restriction map of the $d m p$-operon and its regulatory gene $d m p R$ (Shingler et al., 1993). Arrows indicate the divergent transcription of the two genetic units. Coordinates of restriction endonuclease recognition sites are given in $\mathrm{kb} ; \mathrm{B}, \mathrm{Bam} \mathrm{HI} ; \mathrm{Bg}, \mathrm{Bg} / \mathrm{II}$; E, EcoRI; Ev, EcoRV; P, PstI; Pv, PvuII; Sc, SacI; Sm, SmaI.

Shingler et al., 1992; Powlowski et al., 1993; see Fig. 1) that is regulated by a divergently transcribed transcriptional activator (Shingler et al., 1993). Nucleotide sequences have been reported for all sixteen of these genes, making the meta-cleavage pathway and associated enzymes of Pseudomonas sp. strain CF600 the first for which sequence information is complete.

The first step in aerobic catabolism of phenol is hydroxylation to form catechol. In Pseudomonas CF600 this conversion involves six polypeptides, $\mathrm{P} 0$ to $\mathrm{P} 5$, that are encoded by the $d m p K L M N O P$ genes (Nordlund $e t$ $a l ., 1990)$. However, only the polypeptide products of the dmpLMNOP genes, namely $\mathrm{P} 1, \mathrm{P} 2, \mathrm{P} 3, \mathrm{P} 4$ and $\mathrm{P} 5$, are required for in vitro activity of this multi-component enzyme (Powlowski \& Shingler, 1990).

The multi-component nature of this phenol hydroxylase is intriguing. As a general rule, mono-hydroxylated ring structures such as phenol are oxygenated by single component flavoprotein monooxygenases (Ballou, 1982). For example, genes encoding flavoprotein hydroxylases (monooxygenases) induced by growth on phenol have recently been identified and characterized in a number of micro-organisms, including Pseudomonas pickettii (Kukor \& Olsen, 1992), Pseudomonas EST1001 (Nurk et al., 1991) and the yeast Trichosporon cutaneum (Kälin et al., 1992). The 2,4-dichlorophenol hydroxylases of Acinetobacter and Alcaligenes species have also been shown to be flavoproteins, although these enzymes show no activity with unsubstituted phenol (Beadle \& Smith, 1982; Liu \& Chapman, 1984). On the other hand, studies of phenol degradation in a Bacillus species suggest that the phenol hydroxylase of this organism may not be a simple single component flavoprotein (Gurujeyalakshmi \& Oriel, 1989).

Here we report gene-probing experiments performed on 12 phenol-utilizing bacterial isolates that demonstrate that genes encoding the unusual multi-component CF600 phenol hydroxylase are present in other phenol-degrading bacteria. Moreover, these strains also possess DNA highly homologous to the meta-pathway genes and the specific regulator of phenol catabolism encoded by plasmid pVI150 in Pseudomonas sp. strain CF600.

\section{Methods}

Bacterial strains. Marine bacterial strains were isolated from seawater samples taken downstream of the discharge from a wood pulping mill located on the west coast of Norway. Water samples from a depth of $1 \mathrm{~m}$ were taken at approximately $5 \mathrm{~km}$ intervals from eight different stations and immediately plated onto marine agar (Difco) or minimal M9-salts media containing benzoate $(5 \mathrm{mM})$. Approximately 150 individual colonies from each station were subsequently tested for their ability to grow on phenol as sole carbon and energy source. The ten isolates chosen for analysis in this study (MI1 to MI10), grew on solid and in liquid media with phenol as sole carbon and energy source. Other bacterial strains used are the phenol-utilizing strains $P_{\text {seudo- }}$ monas U (Dagley \& Gibson, 1965) and Pseudomonas sp. strain CF600 (Shingler et al., 1989). Pseudomonas putida PB2701, a streptomycin resistant derivative of KT2440 (Franklin et al, 1981), was used as a control strain that is unable to utilize phenol.

Growth conditions. Pseudomonas U, Pseudomonas sp. strain CF600 and $P$. putida $\mathrm{PB} 2701$ were cultured at $30^{\circ} \mathrm{C}$, while marine isolates were grown at ambient temperature. Luria broth (LB) and marine agar (Difco) were used as rich medium for the Pseudomonas strains and marine strains, respectively. The ability to utilize different aromatic compounds as sole carbon and energy source was tested on minimal M9-salt plates supplemented with the different carbon sources at the concentrations indicated.

Induction of catabolic enzyme activities of marine isolates for crude extract preparations was performed by growth for $2 \mathrm{~d}$ on solid minimal media supplemented with $0.5 \%$ Casamino acids and $2.0 \mathrm{~mm}$-phenol, $o$ cresol or aniline.

Crude extract preparations and enzyme assays. Cells used for making crude extracts were prepared as described by Shingler et al. (1992). Catechol 2,3-dioxygenase (C23O) and catechol 1,2-dioxygenase (C12O) enzyme assays were performed spectrophotometrically at $25^{\circ} \mathrm{C}$ as described by Sala-Trepat $e t$ al. (1972). Extracts used for $\mathrm{C} 12 \mathrm{O}$ activity measurements were pre-treated for $10 \mathrm{~min}$ with $\mathrm{H}_{2} \mathrm{O}_{2}$ at a final concentration of $10 \mathrm{mM}$ to inactivate (Nozaki, 1970), and thus avoid interference by any $\mathrm{C} 23 \mathrm{O}$ present in the protein extract. Units of activity are defined as the amounts of enzyme required to convert $1 \mu \mathrm{mol}$ of substrate to product $\mathrm{min}^{-1}$. Protein concentration in cell extracts was estimated using the BCA assay (Pierce Chemical Co.) with BSA as the standard using the $60^{\circ} \mathrm{C}$ protocol described by the manufacturers.

Southern hybridization and DNA probes. DNA extractions and Southern analysis were performed as described by Sambrook et al. (1989). Washing stringency was as follows: two rinses of 10 and $20 \mathrm{~min}$ duration in $2 \times \mathrm{SSC} / 0.1 \% \mathrm{SDS}$ at room temperature, two washes of $15 \mathrm{~min}$ in $1 \times \mathrm{SSC} / 0.1 \% \mathrm{SDS}$ at $60^{\circ} \mathrm{C}$, followed by two $10 \mathrm{~min}$ washes in $0.25 \times \mathrm{SSC} / 0.1 \% \mathrm{SDS}$ at $60^{\circ} \mathrm{C}$. Filters were stripped for re-probing by boiling for $3 \mathrm{~min}$ in $0.5 \% \mathrm{SDS}$, followed by cooling to room temperature in the SDS solution. 
Table 1. DNA probes

\begin{tabular}{|c|c|c|}
\hline Strains and genes & Oligonucleotide or DNA fragment* & $\begin{array}{l}\text { Reference for } b p \\
\text { coordinates }\end{array}$ \\
\hline Universal probe $\mathbf{A}$ & Oligonucleotide 5'-CGTATTACCGCGGCTGCT-3' & Lane et al. (1985) \\
\hline $\begin{array}{l}\text { Pseudomonas CF600 } \\
\text { derived probes } \\
\text { dmpR } \\
\text { dmpK } \\
\text { dmpL } \\
\text { dmpM } \\
d m p N \\
\text { dmpO } \\
d m p P \\
d m p Q \\
d m p B \\
d m p C \\
d m p D \\
d m p E \\
d m p F \\
d m p G \\
\text { dmpH } \\
\text { dmpI }\end{array}$ & 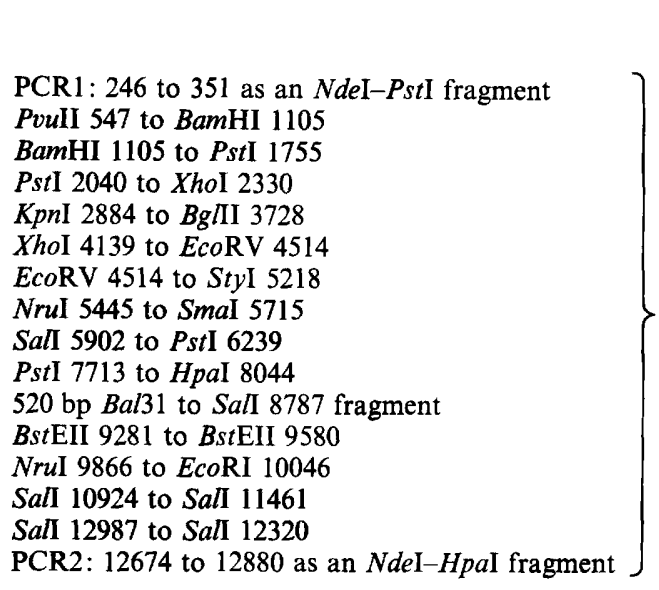 & Shingler et al. (1992) \\
\hline $\begin{array}{l}P . \text { pickettii derived } \\
\text { tbuD } \\
\text { tbuD }\end{array}$ & $\left.\begin{array}{l}\text { EcoRI } 283 \text { to BglII } 519 \\
\text { BglII } 519 \text { to ClaI } 1432\end{array}\right\}$ & Kukor \& Olsen (1992) \\
\hline $\begin{array}{l}\text { Pseudomonas sp. ES } \\
\text { derived probe } \\
\text { phe } A\end{array}$ & BglI 329 to BamHI 1614 & Nurk et al. (1991) \\
\hline $\begin{array}{l}\text { P. putida PB2701 de } \\
\text { probe } \\
\text { rpoN }\end{array}$ & PCR3: a 282 bp fragment $\dagger$ & This study \\
\hline
\end{tabular}

* PCR fragments were generated using the following primers: PCR1 primers 5'-CGCCATATGCCGATCAAGTACAAG-3' and 5'-GCTGAAAACTGCAGCAACAGC-3'; PCR2 primers 5'-CGCCATATGCCGATTGCTCAGCT-3' and 5'-CAAACTGTTAACGAACACTCTC-3'; PCR3 primers 5'-ATGCACGAATCGACCATTTC-3' and 5'-TACTTGGCGACGGTGCGACG-3'.

$\dagger$ The primers used were designed on the basis of conserved regions found upon sequence comparisons of $r p o N$ genes which encode $\sigma^{54}$ factors (Inouye et al., 1989; Kullik et al., 1991).

Initially, $10 \mu \mathrm{g}$ total Pst $\mathrm{I}$ digested DNA from each strain was used and hybridized to a radiolabelled oligonucleotide, universal probe $A$ (Lane et al., 1985), that spans part of the constant region of the $16 \mathrm{~S}$ rRNA. To ensure even loading of genomic equivalents from the 13 strains, some of which harbour plasmids, the resulting autoradiograph was scanned using a Helena laboratories Quick Scan apparatus. Sample loading was adjusted to give an equal intensity signal with the universal probe $A( \pm 15 \%)$. Six essentially identical Southern transfers were made and hybridized with the DNA probes listed in Table 1.

The universal probe A oligonucleotide was 5 '-end labelled using $\left[\gamma{ }^{32} \mathrm{P}\right] \mathrm{dATP}$ (Amersham) and polynucleotide kinase (Boehringer). Double stranded DNA restriction fragments and polymerase chain reaction (PCR)-generated DNA fragments were purified from agarose gels. The resulting DNA was subsequently random-prime labelled using $\left[\alpha^{32} \mathrm{P}\right] \mathrm{dCTP}$ (Amersham) and hexanucleotides (Pharmacia).

\section{Results}

Isolation and growth substrate range of phenol-utilizing marine isolates

The ten phenol-utilizing marine isolates, MI1 to MI10, were isolated from eight sea-water samples and were all found to be Gram-negative rods. The growth substrate range for each of these bacterial isolates was determined and compared with those of three reference strains in Table 2. These bacteria were found to degrade a range of aromatic compounds including methyl-substituted phenols, but none of the chloro-substituted compounds tested. The isolates could be divided into six groups on the basis of their growth substrate range: I, MIl and MI2; IIa, MI3; IIb, MI5; III, MI8; IVa, MI4, MI6 and MI9; IVb, MI7 and MI10. Groups IIa and IIb differed only in their ability to utilize $p$-cresol, while groups IVa and $\mathrm{IVb}$ differed in their ability to utilize aniline. As indicated in Table 2, with the exception of groups IVa and IVb, the members of the different groups were isolated from different samples. The five members of group IVab were isolated from two different water samples on two types of isolation media and therefore represent a minimum of two independent isolates. However, hybridization experiments (see below) using an oligonucleotide complementary to the constant region of 
Table 2. Growth substrate range

Strains were grown at room temperature on minimal M9-media containing the growth substrates, at the indicated concentrations, as sole carbon and energy sources. Groups: (I: MI1, MI2), (IIa: MI3), (IIb: MI5), (III: MI8), (IVa: MI4, MI6, MI9), (IVb: MI7, MI10).

\begin{tabular}{|c|c|c|c|c|c|c|c|c|c|c|c|c|c|}
\hline $\begin{array}{l}\text { Isolate(s) from water sample... } \\
\text { Original isolation medium }{ }^{*} . . \\
\text { Carbon source }\end{array}$ & $\begin{array}{c}8 \\
\text { MA }\end{array}$ & $\begin{array}{c}6 \\
\text { MA }\end{array}$ & $\begin{array}{c}5 \\
\text { MA }\end{array}$ & $\begin{array}{c}4 \\
\text { MA }\end{array}$ & $\stackrel{4}{\mathrm{MA}}$ & $\stackrel{3}{\mathrm{MA}}$ & $\stackrel{3}{\mathrm{MA}}$ & $\begin{array}{c}1 \\
\text { MA }\end{array}$ & $\begin{array}{c}3 \\
\mathrm{MB}\end{array}$ & $\stackrel{3}{\mathrm{MB}}$ & $\begin{array}{c}\text { PB } \\
2701\end{array}$ & $\begin{array}{l}\text { CF } \\
600\end{array}$ & $\begin{array}{c}\text { Pseu. } \\
\mathrm{U}\end{array}$ \\
\hline Phenol (2 mм) & + & + & + & + & + & + & + & + & + & + & - & + & + \\
\hline Catechol (2 mM) & + & + & + & + & + & + & + & + & + & + & + & + & + \\
\hline$m$-Toluate $(2 \mathrm{mM})$ & - & - & - & + & - & + & + & - & + & + & - & - & - \\
\hline Benzoate $(5 \mathrm{~mm})$ & + & + & + & + & + & + & + & - & + & + & + & + & + \\
\hline Aniline ( $2 \mathrm{mM}$ ) & - & - & - & + & - & + & - & - & + & - & - & - & - \\
\hline 3-Chlorobenzoate (1 mM) & - & - & - & - & - & - & - & - & - & - & - & - & - \\
\hline Monochloro-phenols (1 mM) & - & - & - & - & - & - & - & - & - & - & - & - & - \\
\hline Dichloro-phenols (1 mM) & - & - & - & - & - & - & - & - & - & - & - & - & - \\
\hline$p$-Hydroxybenzoate ( $2 \mathrm{~mm}$ ) & + & + & + & + & + & + & + & + & + & + & + & + & + \\
\hline Salicylate $(2 \mathrm{mM})$ & - & - & - & - & - & - & - & + & - & - & - & - & - \\
\hline Naphthalene (vapour) & - & - & - & - & - & - & - & - & - & - & - & - & - \\
\hline 3,4-Dimethylphenol (2 mM) & - & - & - & - & - & - & - & - & - & - & - & + & + \\
\hline$p$-Cresol $(2 \mathrm{mM})$ & + & + & - & + & + & + & + & - & + & + & - & + & + \\
\hline$m$-Cresol (2 mM) & + & + & - & + & - & + & + & - & + & + & - & + & + \\
\hline$o$-Cresol (2 mM) & - & - & - & + & - & + & + & - & + & + & - & + & + \\
\hline
\end{tabular}

* MA, marine agar; MB, minimal benzoate containing medium.

Table 3. Ring-fission enzyme activities of marine isolates

Values shown are means of duplicate determinations. Assays were performed a minimum of two times; one representative set of results is shown. The specific activity values of duplicate assays performed on the same crude extract were within $5 \%$, while assays performed on the same strain on different days were usually within twofold.

\begin{tabular}{|c|c|c|c|c|c|c|c|c|}
\hline \multirow[b]{3}{*}{ Strain } & \multirow[b]{3}{*}{ Group } & \multirow{3}{*}{$\begin{array}{c}\text { Growth } \\
\text { substrate... }\end{array}$} & \multicolumn{6}{|c|}{ Enzyme activity [mU (mg protein $\left.)^{-1}\right]$} \\
\hline & & & \multicolumn{2}{|c|}{ Phenol } & \multicolumn{2}{|c|}{$o$-Cresol } & \multicolumn{2}{|c|}{ Aniline } \\
\hline & & & $\mathrm{C} 23 \mathrm{O}$ & $\mathrm{C} 12 \mathrm{O}$ & $\mathrm{C} 23 \mathrm{O}$ & $\mathrm{C} 12 \mathrm{O}$ & $\mathrm{C} 23 \mathrm{O}$ & $\mathrm{C} 12 \mathrm{O}$ \\
\hline MI1 & I & & 230 & 390 & & & & \\
\hline MI2 & I & & 240 & 410 & & & & \\
\hline MI3 & IIa & & $<10$ & 160 & & & & \\
\hline MI4 & IVa & & 800 & $<30$ & 450 & $<30$ & $<10$ & 330 \\
\hline MI5 & $\mathrm{IIb}$ & & $<10$ & 260 & & & & \\
\hline MI6 & IVa & & 710 & $<30$ & 460 & $<30$ & $<10$ & 280 \\
\hline MI7 & IVb & & 910 & $<30$ & 300 & $<30$ & & \\
\hline MI8* & III & & $<10$ & $<30$ & & & & \\
\hline MI9 & IVa & & 760 & $<30$ & 640 & $<30$ & $<10$ & 320 \\
\hline MI10 & $\mathrm{IVb}$ & & 710 & $<30$ & 310 & $<30$ & & \\
\hline
\end{tabular}

* Repeated attempts to prepare crude extracts and detect enzyme activities were unsuccessful.

the $16 \mathrm{~S}$ rRNA and 17 gene-specific DNA probes did not reveal any polymorphism.

\section{Expression of ring-cleavage enzymes}

$\mathrm{C} 23 \mathrm{O}$ and $\mathrm{C} 12 \mathrm{O}$ catalyse the ring-fission step of the meta- and ortho-cleavage pathways respectively. The enzyme activities in crude extracts from the marine isolates were measured to determine which of these two pathways is used for growth on different aromatic substrates. Table 3 shows a summary of the results. Group I isolates are unusual in that they simultaneously expressed both $\mathrm{C} 23 \mathrm{O}$ and $\mathrm{C} 12 \mathrm{O}$ in response to growth on phenol. Group IIa and IIb expressed only $\mathrm{C} 12 \mathrm{O}$ when grown on phenol, while groups IVa and IVb expressed only $\mathrm{C} 23 \mathrm{O}$ when grown on phenol or o-cresol (2methylphenol). Group IVa grew on aniline while group $\mathrm{IVb}$ could not; however, growth on aniline elicited 

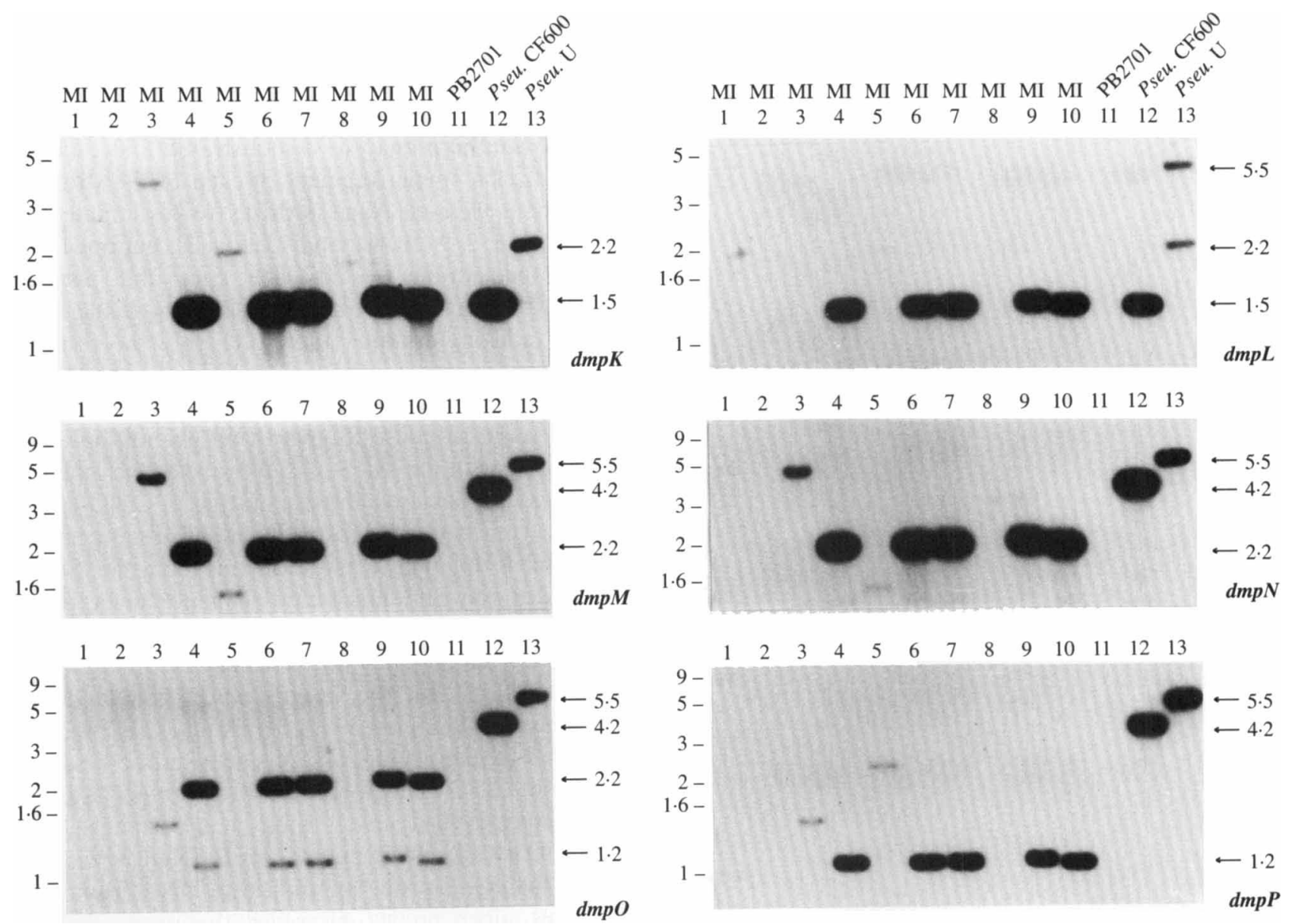

Fig. 2. Autoradiographs of Southern analysis of total PstI digested DNA of bacterial strains hybridized with radiolabelled probes (dmpK, $L, M, N, O$ and $P$ ) specific for the multi-component phenol hydroxylase of Pseudomonas sp. strain CF600. Molecular size standards are given in $\mathrm{kb}$ on the left, and the sizes of major hybridizing bands are indicated with arrows on the right.

expression of $\mathrm{C12O}$, as opposed to $\mathrm{C} 23 \mathrm{O}$. Therefore, it appeared that while groups IVa and IVb both utilize a meta-cleavage pathway to dissimilate phenol and $o$ cresol, only group IVa used an ortho-cleavage pathway to dissimilate aniline. Despite repeated attempts, neither $\mathrm{C} 23 \mathrm{O}$ nor $\mathrm{C} 12 \mathrm{O}$ activity could be detected in crude extracts from MI8. This appears to be an unusual isolate since its DNA did not hybridize with any of the probes directed to either catabolic or non-catabolic genes (see below), although it did hybridize an oligonucleotide complementary to the constant region of the 16S rRNA (data not shown).

\section{Southern analysis using phenol hydroxylase specific probes}

Southern analysis was performed to compare the phenol catabolic genes of the marine isolates with those of phenol-utilizing Pseudomonas CF600 and Pseudomonas $\mathrm{U}$. Hybridization and stringency conditions were the same for all probes used in the analysis. In intact cells, the multi-component phenol hydroxylase activity of Pseudomonas CF600 involves six polypeptides, P0 to P5, encoded by $d m p K L M N O P$ (see Fig. 1). Fig. 2 shows the results of Southern analysis using specific probes directed towards the individual genes encoding the multi-component phenol hydroxylase. DNA derived from all the strains that utilize a meta-cleavage pathway for dissimilation of phenol, groups IVa, IVb, Pseudomonas U and Pseudomonas CF600, strongly hybridized the six probes with approximately equal intensity (lanes 4, 6, 7, 9, 10, 12 and 13, Fig. 2). DNA derived from $P$. putida PB2701, which cannot catabolize phenol, from MI8, or from group I isolates, did not hybridize with any of the probes (lanes 1, 2, 8 and 11; Fig. 2). DNA derived from group IIa and IIb isolates showed low level hybridization with some of the probes (lanes 3 and 5, Fig. 2). Hence, the results demonstrate that DNA highly homologous to the genes encoding $\mathrm{P} 0$ to $\mathrm{P} 5, d m p K L M N O P$, is present in all the bacterial strains tested that utilize a meta-cleavage pathway to catabolize phenol.

In order to investigate the possible nature of the 

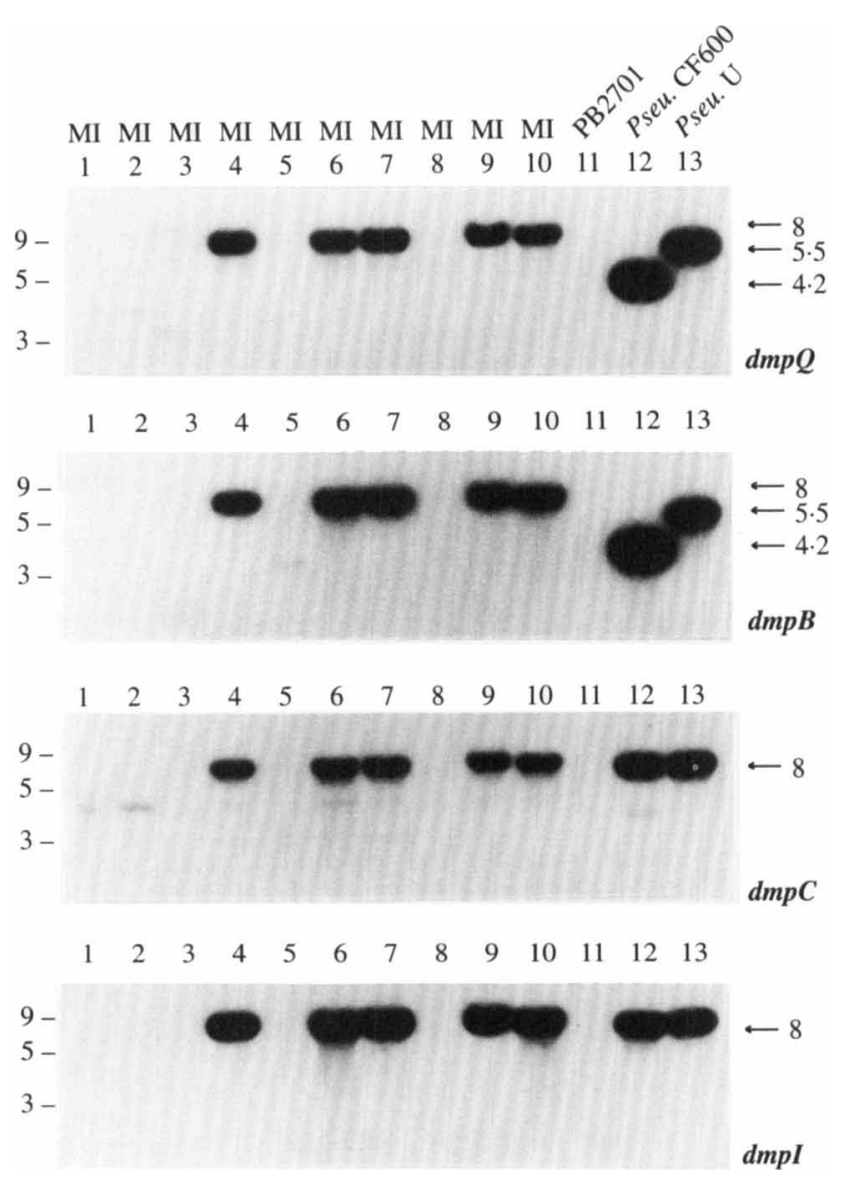

Fig. 3. Autoradiographs of Southern analysis of total PstI digested DNA of bacterial strains hybridized with radiolabelled probes specific for genes encoding meta-pathway enzymes of Pseudomonas sp. strain CF600. Molecular size standards are given in $\mathrm{kb}$ on the left, and the sizes of major hybridizing bands are indicated with arrows on the right.

phenol hydroxylase exhibited by groups I, IIab and III, probes for two other phenol hydroxylases were used. These probes, derived from tbuD from Pseudomonas pickettii and pheA from Pseudomonas EST1001, are specific to phenol hydroxylase genes that encode single component flavoprotein hydroxylases. Despite the fact that these two genes both encode flavoprotein hydroxylases, they share little overall sequence homology at the nucleotide level (Kukor \& Olsen, 1992). None of the three probes tested gave specific hybridization signals with DNA from any of the phenol-degrading isolates (data not shown). Therefore, the nature of the phenol hydroxylase encoded by these strains remains unclear.

\section{Southern analysis using meta-pathway specific probes}

To investigate further the genetic composition of groups IVa and IVb in terms of their meta-cleavage pathway, nine $d m p$-operon probes were used. The $d m p$-operon genes lie in the order $d m p Q B C D E F G H I$ (see Fig. 1).
DmpQ is a small ferredoxin-like protein whose function is as yet unknown (Shingler et al., 1992). The dmpBCDEFGHI genes encode the meta-cleavage pathway enzymes (see Shingler et al., 1992; Powlowski et al., 1993). Southern analysis demonstrated that each probe hybridizes a single fragment of each of the strains that utilized a meta-cleavage pathway to dissimilate phenol (lanes 4, 6, 7, 9, 10, 12, and 13, Fig. 3), but not DNA of the other strains tested. The sizes and pattern of hybridization using the $d m p C, D, E, F, G, H$ and $I$ probes were indistinguishable; therefore, only the results obtained using the $d m p Q, B, C$ and $I$ probes are shown.

Group I isolates produced both $\mathrm{C} 23 \mathrm{O}$ and $\mathrm{C} 12 \mathrm{O}$ activities in response to growth on phenol, but did not hybridize with the $d m p B-C 230$ probe or the other metapathway probes used above. Analysis of $\mathrm{C} 23 \mathrm{O}$-encoding genes from a number of different bacterial genera has identified different classes of this enzyme. Southern hybridization and nucleotide sequence determinations have demonstrated that homology between different C23O-encoding genes varies from very low to approximately $85 \%$ for the $d m p B, n a h H$ and $x y l E$ genes (Bartilson \& Shingler, 1989; Benjamin et al., 1991). In an attempt to identify the C23O-gene of group I isolates, a range of C23O-gene probes were used; $m p c I$ (Kabisch \& Fortnagel, 1990a); mpcII (Kabisch \& Fortnagel, 1990b); C23DO (Keil, 1990) and C23O II (Keil et al., 1985). Only the mpcII-probe hybridized to DNA from group I isolates, albeit poorly. However, this probe also hybridized, with equal intensity, to DNA fragments from all but MI8 (data not shown). Therefore, the nature of the C23O-encoding gene of group I isolates remains obscure.

\section{Southern analysis using gene-expression probes}

In view of the homology seen between groups IVa and $b$, Pseudomonas U and Pseudomonas CF600 to the multicomponent phenol hydroxylase and meta-pathway genes, Southern analysis was also performed using components of the $d m p$-operon regulatory system. The $d m p$-operon is positively regulated by the divergently transcribed $d m p R$ gene product (see Fig. 1). DmpR shares homology with the NtrC family of transcriptional activators. However, only XylR, a regulator of the catabolic pathway of pWW0, was found to share homology with the $\mathrm{N}$ terminal domain of DmpR (Shingler et al., 1993). Therefore, we performed Southern analysis using a probe derived from the $5^{\prime}$-end of $d m p R$. The results, shown in Fig. 4, demonstrate that this probe specifically hybridizes to DNA of group IVab, Pseudomonas U and Pseudomonas CF600, but not to DNA of the other marine isolates or $P$. putida $\mathrm{PB} 2701$.

DmpR and other members of the NtrC family regulate transcription from promoters recognized by RNA 


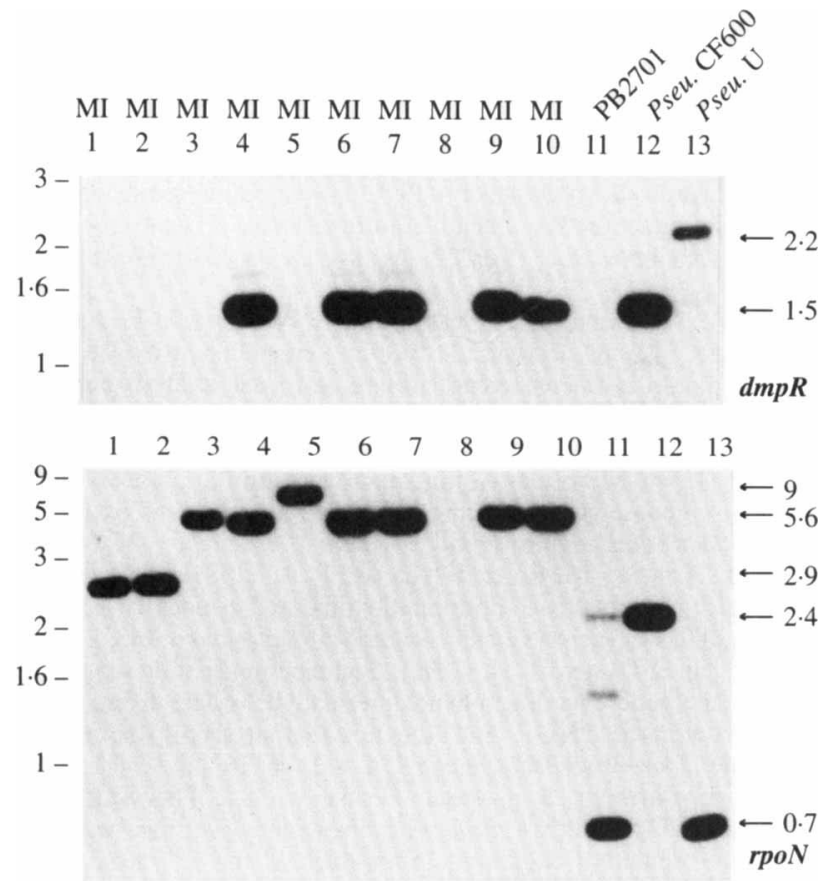

Fig. 4. Autoradiographs of Southern analysis of total PstI digested DNA of bacterial strains hybridized with radiolabelled probes specific for genes involved in transcriptional regulation. The $d m p R$-probe was derived from Pseudomonas sp. strain $\mathrm{CF} 600$ and the rpoN-probe from $P$. putida PB2701 (see Methods). Molecular size standards are given in $\mathrm{kb}$ on the left, and the sizes of major hybridizing bands are indicated with arrows on the right.

polymerase employing the alternative sigma factor $\left(\sigma^{54}\right)$ encoded by rpoN or its homologues (see Inouye et al., 1989). Southern analysis, using an rpoN-PCR fragment generated using $P$. putida PB2701 DNA, is shown in Fig. 4. DNA from all strains, except MI8, was found to hybridize with this gene probe.

\section{Discussion}

The multi-component phenol hydroxylase of Pseudomonas CF600 comprises five polypeptides, $\mathrm{P} 1$ to $\mathrm{P} 5$. The P5 polypeptide contains FAD and a ferredoxin-type iron-sulphur centre, and can catalyse the transfer of electrons from NADH, which is required for oxygenase activity. $\mathrm{P} 2$ is a small essential polypeptide of unknown function, while the P1, P3 and P4 polypeptides form an oxygenase complex (Powlowski \& Shingler, 1990, and unpublished data). The multi-component phenol hydroxylase is novel in a number of ways. Firstly, the multicomponent nature of this enzyme was unexpected since reactions of this type are usually catalysed by single component flavoproteins (Ballou, 1982). Secondly, the multi-component phenol hydroxylase system, surprisingly, shows organizational similarity and low level sequence identity with components of oxygenases for unactivated compounds such as methane monooxygenase and toluene-4-monooxygenase (Powlowski \& Shingler, 1990; Harayama et al., 1991; Yen et al., 1991). The unusual nature of the multi-component phenol hydroxylase prompted us to ask in this study if similar systems are used in other phenol-utilizing bacteria. In some other Pseudomonas species, it is clear that a multi-component phenol hydroxylase is not involved (Kukor \& Olsen, 1992; Nurk et al., 1991). However, it is conceivable that multi-component phenol hydroxylases have previously been overlooked due to the difficulties associated with the in vitro assay (Powlowski \& Shingler, 1990).

Southern hybridization analysis, using DNA probes specific for the components of the phenol hydroxylase of CF600, demonstrated that five out of ten phenol-utilizing marine bacterial isolates (groups IVa and b), and the archetypal phenol-degrader Pseudomonas U, all possessed DNA highly homologous to each of the components of Pseudomonas CF600 phenol hydroxylase. All of these strains utilize a meta-pathway and were also found to possess DNA highly homologous to all nine meta-cleavage pathway genes of Pseudomonas CF600, and to the specific regulator of phenol catabolism of this strain. Examination of the sizes and order of the hybridizing DNA fragments (Figs 2 to 4 ) suggests that not only are the structural genes and regulatory genes for phenol catabolism conserved, but they are probably also encoded in the same order in all the strains.

The phenol catabolic pathway of Pseudomonas CF600 is located on the megaplasmid pVI150, which has a copy number of one to two (from unpublished data), while that of Pseudomonas $\mathrm{U}$ is believed to be chromosomally encoded. The genetic locations of the phenol catabolic pathway genes of the five marine isolates of groups IVa and IVb are not known. However, on the basis of the intensity of hybridization signals of genomic equivalents, they are probably located on either the chromosome or a low copy number plasmid.

Clustering and homology of meta-cleavage pathway genes of different bacterial genera isolated from diverse geographical locations has been documented for a number of years (Assinder \& Williams, 1990). Many aromatic catabolic pathways are encoded on plasmids, and in some cases have been found to be either wholly or partially encoded within large transposons. The genetic events, including conjugation, transposition and recombination, that probably lead to adaptation for growth on aromatic compounds have recently been reviewed by van de Meer et al. (1992). Conservation of central pathways (i.e. meta- or ortho-pathways) has led to the idea that catabolic pathways are built up piecemeal by the acquisition of pre-evolved 'metabolic modules' (Assinder \& Williams, 1990). Hence, different degrada- 
tive bacteria might be expected to possess homologous central pathways for the dissimilation of catechol(s). However, the genetic location, the enzyme systems for conversion of substrates to catecholic intermediate, and catabolic regulatory systems, are usually different.

Pseudomonas CF600 was originally isolated from an activated sludge sample from the British Carbonisation Research Association, Pseudomonas U from the mud of a stream in Urbana, USA, and the marine bacterial isolates from sea water collected off the coast of Norway. These strains represent an example of conservation of both a specific regulatory gene and structural genes whose products are involved in both substrate conversion to a central intermediate and in the subsequent metacleavage pathway. Hence, it seems likely that these strains inherited both structural and specific regulatory genes involved in phenol utilization as a single metabolic unit.

This research was supported by The Centre for Environmental Research Umeå, The Swedish Research Council for Engineering Science, and The Swedish Natural Science Research Council. We wish to thank Drs P. Fortnagel, M. Kivisaar, H. Keil, J. Kukor, R. H. Olsen and P. A. Williams for providing DNA constructs.

\section{References}

Assinder, S. J. \& Williams, P. A. (1990). The TOL plasmids: determinants of the catabolism of toluene and xylenes. Advances in Microbiological Physiology 31, 1-69.

Ballou, D. (1982). Flavoprotein monooxygenases. In Flavin and Flavoproteins, pp. 301-310. Edited by V. Massey \& C. H. Williams. New York: Elsevier/North Holland Publishing.

BARTILSON, M. \& SHINGLER, V. (1989). Nucleotide sequence and expression of the catechol 2,3-dioxygenase gene of phenol catabolizing Pseudomonas CF600. Gene 85, 233-238.

Bartilson, M., Nordlund, I. \& ShIngler, V. (1990). Location and gene organisation of the dimethylphenol catabolic genes of Pseudomonas CF600. Molecular and General Genetics 220, 294-300.

BEADle, C. A. \& SMrth, A. R.W. (1982). The purification and properties of 2,4-dichlorophenol hydroxylase from a strain of Acinetobacter species. European Journal of Biochemistry 123, 323332.

Benjamin, R. C., Voss, J. A. \& Kunz, D. A. (1991). Nucleotide sequence of $x y l E$ from the TOL $\mathrm{pDK} 1$ plasmid and structural comparison with isofunctional catechol-2,3-dioxygenase genes from TOL pWW0 and NAH7. Journal of Bacteriology 173, 2724-2728.

DAGLEY, S. (1986). Biochemistry of aromatic hydrocarbon degradation in pseudomonads. In The Bacteria, vol. X, The Biology of Pseudomonas, pp. 527-556. Edited by J. R. Sokatch. London: Academic Press.

Dagley, S. \& Gibson, D. T. (1965). The bacterial degradation of catechol. Biochemistry Journal 95, 466-474.

Franklin, F. C. H., Bagdasarian, M., Bagdasarian, M. M. \& TIMmIS, K. N. (1981). Molecular and functional analysis of the TOL plasmid pWWO from Pseudomonas putida and cloning of genes for the entire regulated aromatic ring meta-cleavage pathway. Proceedings of the National Academy of Sciences of the United States of America 18, 7458-7462.

GurujeyalaKshmi, G. \& ORIEL, P. (1989). Isolation of phenol degrading Bacillus stearothermophilus. Applied and Environmental Microbiology 55, 500-502.

Harayama, S., Polissi, A. \& Rekik, M. (1991). Divergent evolution of chloroplast-type ferredoxins. FEBS Letters 285, 85-88.
Inouye, S., Yamada, M., Nakazawa, A. \& Nakazawa, T. (1989). Cloning and sequence analysis of the ntrA (rpoN) gene of Pseudomonas putida. Gene 85, 145-152.

KABISCH, M. \& ForTNAGEL, P. $(1990 a)$. Nucleotide sequence of the metapyrocatechase I (catechol 2,3-dioxygenase I) gene $\mathrm{mpcI}$ from Alcaligenes eutrophus JMP222. Nucleic Acids Research 18, 5543.

KABISCH, M. \& ForTNAGEL, P. (1990b). Nucleotide sequence of the metapyrocatechase II (catechol 2,3-dioxygenase II) gene mpcII from Alcaligenes eutrophus JMP222. Nucleic Acids Research 18, 34053406.

Kälin, M., Neujahr, H. Y., Wessmahr, R. N., Sejlitz, T., Jöhl, R., FIECHTER, A. \& ReIser, J. (1992). Phenol hydroxylase from Trichosporon cutaneum: gene cloning, sequence analysis and functional expression in Escherichia coli. Journal of Bacteriology 174, $7112-7120$.

KEIL, H. (1990). Molecular cloning and expression of a novel catechol 2,3-dioxygenase gene from the benzoate meta-cleavage pathway in Azotobacter vinelandii. Journal of General Microbiology 136, 607-613.

Keil, H., Lebens, M. R. \& Williams, P. A. (1985). TOL plasmid pWW15 contains two nonhomologous, independently regulated catechol 2,3-oxygenase genes. Journal of Bacteriology 163, 248-255.

KUKOR, J. J. \& OLSEN, R. H. (1992). Complete nucleotide sequence of $t b u D$, the gene encoding phenol/cresol hydroxylase from Pseudomonas pickettii $\mathrm{PKO1}$, and functional analysis of the encoded enzyme. Journal of Bacteriology 174, 6518-6526.

Kullik, I., Fritsche, S., KNOBel, H., SANJuan, J., Hennecke, H. \& FisCHER, H.-M. (1991). Bradyrhizobium japonicum has two differentially regulated, functional homologs of the $\sigma^{54}$ gene (rpoN). Journal of Bacteriology 173, 1125-1138.

Lane, D. J., Pace, B., Olsen, G. J., Stahl, D. A., Sogin, M. L. \& PACE, N. R. (1985). Rapid determination of 16 S ribosomal RNA sequences for phylogenetic analysis. Proceedings of the National Academy of Sciences of the United States of America 82, 6955-6959.

LIU, T. \& ChapMaN, P. J. (1984). Purification and properties of a plasmid-encoded 2,4-dichlorophenol hydroxylase. FEBS Letters 173 , 314-318.

Nordlund, I., Powlowski, J. \& SHINGler, V. (1990). Complete nucleotide sequence and polypeptide analysis of multicomponent phenol hydroxylase from Pseudomonas sp. strain CF600. Journal of Bacteriology 172, 6826-6833.

NORDLUND, I. \& SHINGLeR, V. (1990). Nucleotide sequences of the meta-cleavage pathway enzymes 2 -hydroxymuconic semialdehyde dehydrogenase and 2-hydroxymuconic semialdehyde hydrolase from Pseudomonas CF600. Biochimica et Biophysica Acta 1049, 227-230.

NozAKI, M. (1970). Metapyrocatechase (Pseudomonas). Methods in Enzymology 17, 522-525.

Nurk, A., Kasak, L. \& KivisaAR, M. (1991). Sequence of the gene (pheA) encoding phenol monooxygenase from Pseudomonas EST1001: expression in Escherichia coli and Pseudomonas putida. Gene 102, 13-18.

POWLOWSKI, J. \& SHINGLER, V. (1990). In vitro analysis of polypeptide requirement of multicomponent phenol hydroxylase from Pseudomonas sp. strain CF600. Journal of Bacteriology 172, 6834-6840.

Powlowski, J., Sahlman, L. \& ShINGleR, V. (1993). Purification and properties of the physically associated meta-pathway enzymes, 4 . hydroxy-2-oxovalerate aldolase and acetaldehyde dehydrogenase (acylating), from Pseudomonas sp. strain CF600. Journal of Bacteriology 175, 377-385.

REINEKE, W. \& KNACKMUSS, H.-J. (1988). Microbial degradation of haloaromatics. Annual Review of Microbiology 42, 263-287.

Sala-Trepat, J. M., Murray, K. \& Williams, P. A. (1972). The metabolic divergence in the meta-cleavage of catechols by Pseudomonas putida NCIB10015, physiological significance and evolutionary implications. European Journal of Biochemistry 28, 347-356.

Sambroox, J., Fritsch, E. F. \& Maniatis, T. (1989). Molecular Cloning: A Laboratory Manual. Cold Spring Harbor, NY: Cold Spring Harbor Laboratory.

Shingler, V., Franklin, F. C. H., Tsuda, M., Holroyd, D. \& Bagdasarian, M. (1989). Molecular analysis of a plasmid encoded phenol hydroxylase from Pseudomonas CF600. Journal of General Microbiology 135, 1083-1092.

Shingler, V., Powlowski, J. \& Marklund, U. (1992). Nucleotide 
sequence and functional analysis of the complete phenol/3,4dimethylphenol catabolic pathway of Pseudomonas sp. strain CF600. Journal of Bacteriology 174, 711-724.

SHINGleR, V., BARTILSON, M. \& MOORE, T. (1993). Cloning and nucleotide sequence of the positive regulator (DmpR) of the phenol catabolic pathway encoded by pVI150 and identification of DmpR as a member of the NtrC family of transcriptional activators. Journal of Bacteriology 175, 1596-1604.
Van de Meer, J. R., de Vos, W. M., Harayama, S. \& Zehnder, A. J. B. (1992). Molecular mechanisms of genetic adaptation to xenobiotic compounds. Microbiological Reviews 56, 677-694.

Yen, K.-M., KarL, M. R., Blatt, L. M., Simon, M. J., Winter, R. B., Fausset, P. R., Lu, H. S., Harcourt, A. A. \& Chen, K. K. (1991). Cloning and characterisation of a Pseudomonas mendocina KR 1 gene cluster encoding toluene-4-monooxygenase. Journal of Bacteriology 173, 5315-5327. 